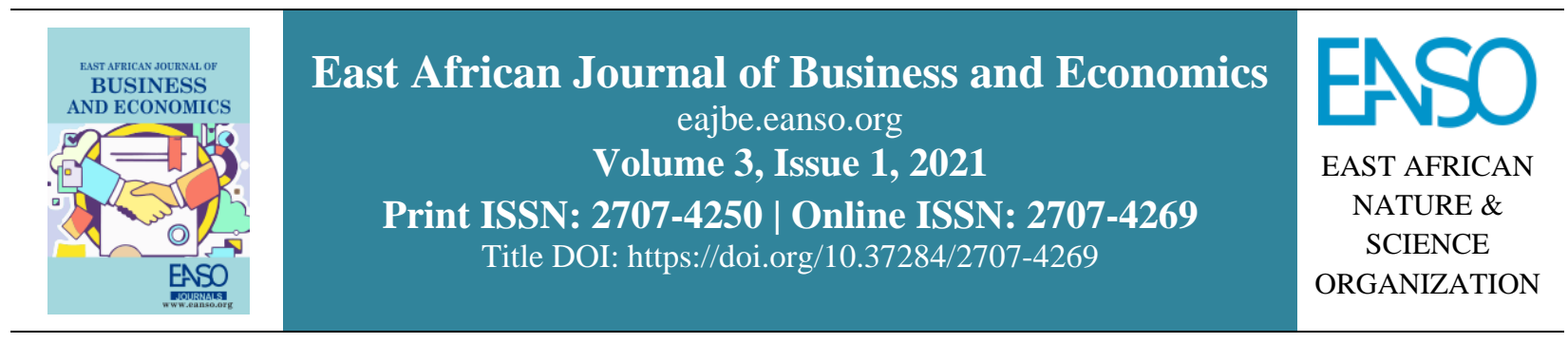

Original Article

\title{
Effect of Foreign Exchange Reserves and Money Supply on Exchange Rate in South Sudan.
}

\author{
Wuor Chuol Both ${ }^{1 *}$ \\ ${ }^{1}$ University of Juba, P. O. Box 82, Juba, Juba-South Sudan. \\ * ORCID ID: 0000-0001-8779-5982; Correspondence email: wuorboth@ gmail.com.
}

Article DOI: https://doi.org/10.37284/eajbe.3.1.353

\section{Date Published: ABSTRACT}

O2 July 2021 Since the establishment of the Central Bank of South Sudan in 2011, monetary policymakers have been changing their policy instruments over the years in an

Keywords: attempt to stabilise the country's economy. This study investigated the effect

Exchange Rate, of foreign exchange reserves and money supply on the exchange rate in South Foreign Exchange

Reserves, Money Supply,

South Sudan. Sudan over the period 2012 to 2019. Empirical studies of the effect of foreign exchange reserves and money supply on the exchange rate are reviewed in both developed and developing countries. Annual data from the World Bank Economy Statistics Database was analysed using an advanced pivot table. The findings of this study indicate that a decrease in foreign exchange reserves causes a depreciation in the exchange rate. The results also confirm that an increase in money supply causes depreciation in the exchange rate. The findings are in line with the findings of all the empirical studies that are reviewed in this paper.

\section{APA CITATION}

Both, W. C. (2021). Effect of Foreign Exchange Reserves and Money Supply on Exchange Rate in South Sudan. East African Journal of Business and Economics, 3(1), 122-129. https://doi.org/10.37284/eajbe.3.1. 353

\section{CHICAGO CITATION}

Both, Wuor Chuol. 2021. "Effect of Foreign Exchange Reserves and Money Supply on Exchange Rate in South Sudan:.". East African Journal of Business and Economics 3 (1), 122-129. https://doi.org/10.37284/eajbe.3.1. 353

\section{HARVARD CITATION}

Both, W. C. (2021) "Effect of Foreign Exchange Reserves and Money Supply on Exchange Rate in South Sudan.", East African Journal of Business and Economics, 3 (1), pp. 122-129. doi: 10.37284/eajbe.3.1. 353

\section{IEEE CITATION}

W. C. Both, "Effect of Foreign Exchange Reserves and Money Supply on Exchange Rate in South Sudan.", EAJBE, vol. 3, no. 1, pp. 122-129, Jul. 2021.

122| This work is licensed under a Creative Commons Attribution 4.0 International License. 


\section{MLA CITATION}

Both, Wuor Chuol. "Effect of Foreign Exchange Reserves and Money Supply on Exchange Rate in South Sudan.". East African Journal of Business and Economics, Vol. 3, no. 1, Jul. 2021, pp. 122-129, doi:10.37284/eajbe.3.1.353

\section{INTRODUCTION}

Given the importance of economic growth in any country, the main focus of government policymakers and economists/monetary policymakers are to have fast and sustainable economic growth. One of the most vital macroeconomics tools any government can use is its monetary policy since money is essential for the smooth functioning of an economy (Yongo-Bure, 2014). In light of this, many governments globally have been anxious to maintain the exchange rate stability in their countries because it is the most important price in any economy, affecting all other prices (Frieden, 2016). In South Sudan, however, there are few or no efforts at all made to study the determinants of the exchange rate despite the fact that for the past eight years the country had recorded the worst levels of exchange rate depreciation since it gained its independence in July 2011. According to the theoretical and empirical literature, the exchange rate is influenced by many factors such as foreign exchange reserves, money supply, interest rate, terms of trade, trade openness, government expenditure, and the demand for a country's goods and services. However, this paper only examines the influence of foreign exchange reserves and money supply on the exchange rate.

The exchange rate is defined as the value at which a domestic currency is trading for another country's currency (Obura \& Anyango, 2015). The exchange rate is also defined as the amount of a currency that one needs in order to buy one unit of another currency, or it is the amount of a currency that one receives when selling one unit of another currency (Sercu, 2009). There are two main types of exchange rate regimes, namely fixed exchange rate and float/flexible exchange rate regimes. In a fixed exchange rate regime, the value of the currency is determined by the government while in the case of a float/flexible exchange rate regime, the value of the currency is market-determined and the government does not play any role in its stabilisation (Semuel \& Nurina, 2014). According to Aleksandra (2019), exchange rate movements can have significant effects on various economic variables, affecting the overall macroeconomic stability of the country. Thus, monetary policymakers should ensure that the right monetary policy adjustment is done on money supply, foreign exchange reserves and other monetary policy instruments.

Foreign exchange reserves are defined as assets held on reserve by a monetary authority in foreign currencies (Wyplosz, 2007). Such assets are normally used to back liabilities and influence monetary policy. One of the most significant uses is to ensure the government has backup funds if its national currency devalues rapidly. In recent years, many countries, especially developing countries, have been seen to increase their foreign exchange reserves so as to meet not only interventions in exchange rate markets and maintaining confidence in the currency but also serving as a basis for foreign borrowing. The foreign exchange reserve policy was established from the time when the Bretton Wood system was set up immediately after World War II. Until now, it has been regarded as a common practice in many countries globally for their central bank to hold a certain number of reserves in their foreign exchange. These reserves are mostly held in United States (US) dollars since it is the most widely traded currency in the world (Kashif \& Sridharan, 2015). However, over the years the question of the right amount of foreign exchange reserves a country can hold to stabilise its economic variables has been an ongoing issue in monetary economics and central banking literature. Some economists argued that the foreign exchange reserves should be equal to short-term external debt while others support the idea of it being equal to three or four months of imports (Glavan, 2006).

The money supply is defined as the total amount of money (e.g., currency and demand deposits) in circulation in a country at any given time (Anyanwu, 1993). For the purposes of this paper, the broad definition of money supply (M2+) is adopted which includes currency in circulation, demand deposits, quasi-money and foreign currency deposits. There are two criteria that are used in measuring money supply. The first criterion defines the stock of narrow money (usually designated by 
M1) as currencies and coins in circulation in the hands of the non-banking public and the demand deposit (of the non-banking public) with a commercial bank (Ajakaiye, 1995). In any country, the money supply in an economy is regulated by its central bank. The central bank always determines the amount of money in existence as well as the number of checking deposits issued by private/commercial banks. However, there is no agreed-upon formula to determine the size of the money supply a country's central bank should release into the economy. Therefore, the debate on the right size of the money supply to be released in an economy is ongoing.

\section{LITERATURE REVIEW}

In order to have a deeper understanding of this study, various empirical studies on the effect of foreign exchange rate reserves and money supply on the exchange rate are reviewed in both developed and developing countries. This study also consulted detailed reports on the South Sudan Central Bank and databases such as the World Bank Economy Statistics Database.

Yu and Lili (2011) examined whether a correlation exists between foreign exchange reserves and the exchange rate in China. The study implemented various test models to analyse four main variables, namely foreign exchange reserves, foreign exchange rate, the total volume of import and export trade, and gross domestic product (GDP). By means of the Granger causality test, the study found that the foreign exchange rate is NOT the Granger cause of foreign exchange reserves, but that the foreign exchange reserves are the Granger cause of the foreign exchange rate. In other words, any changes in foreign exchange reserves would lead to the fluctuation of the renminbi (RMB) exchange rate but not vice versa (Yu \& Lili, 2011). In addition, Hoshikawa (2012) examined the long-term relationship between the yen/dollar exchange rate and international reserves using the ADF test, the cointegration test, and dummy variables as analysis instruments. The results of the study indicated that a long-term relationship exists between Japanese foreign exchange reserves and the yen/dollar exchange rate.
Arikekpar (2020) investigated the stability of the exchange rate in Nigeria from 1990 to 2007. The study deployed a cointegration test, ordinary least square and Granger causality test to analyse variables such as credit reserves, broad money supply, interest rate, inflation rate and exchange rate. The results of the study indicated that there is a negative relationship between the credit reserve requirement and exchange rate. However, on the other variables, it was found that broad money supply, interest rate and inflation rate have a positive relationship with the exchange rate in the country (Arikekpar, 2020). Furthermore, Vasani, Selvam and Kathiravan (2019) examined the relationship between the real exchange rate and economic growth in India for the period from Q1 2005 to Q4 2017, considering the variables such as the nominal exchange rate, consumer price index, balance of payments, exports, foreign exchange reserves, gross domestic product, imports, inflation, international reserves and money supply. The study deployed the Johansen cointegration test, Granger causality and ADF stationary tests for the purpose of analysis. The Granger causality test revealed that the real exchange rate recorded a unidirectional relationship with exports, foreign exchange reserves and money supply. The results of the linear regression for the study found that imports and money supply affected the real exchange rate (Vasani et al., 2019).

Raza and Afshan (2017) examined the determinants of the exchange rate in Pakistan by using the timeseries data for the period from 1972 to 2013. The study applied an autoregressive distributed lag bound testing cointegration approach, the Johansen and Juselius cointegration approach and the Gregory and Hansen structural break cointegration approach on several variables (terms of trade, trade openness, economic growth, exchange rate, inflation rate and money supply). The results of the study indicate that there is a significant negative association of exchange rates with terms of trade, trade openness and economic growth. However, money supply and inflation rate have a positive and significant effect on exchange rates. Kasman and Ayhan (2008) investigated the relationship between exchange rates (nominal and real) and foreign exchange reserves in Turkey. The study applied monthly data over the period 1982:1-2005:11. Unit root and cointegration tests that allow for structural 
breaks were deployed. The results of the study indicate that there is a long-term relationship between foreign exchange reserves and exchange rates. The results also suggest that the direction of both long- and short-run causality is from foreign exchange reserves to the real effective exchange rate but not vice versa (Kasman \& Ayhan, 2008).

\section{Conceptual Framework}

Researchers use different types of tools or methods in research to enable them to achieve an Figure 1: Conceptual Model

\begin{tabular}{|l|}
\hline INDEPENDENT VARIABLES \\
- \\
- \\
Moreign Exchange Reserves \\
\end{tabular}

Foreign exchange reserves and money supply are deployed to be independent variables, the fluctuation effects of which are to be examined on dependent variables, the exchange rate.

\section{RESULTS AND DISCUSSIONS}

\section{Monetary Operating Procedures in South Sudan from 2006-2019}

The Bank of Southern Sudan (BOSS) was first established as a branch of the Central Bank of Sudan in 2005 to provide, in addition to its other functions, conventional banking services in South Sudan, including licenses to the financial institutions during the period of the Comprehensive Peace Agreement (CPA) implementation. However, immediately after the country's secession on July 9 2011, BOSS became the Central Bank of South Sudan. The Central Bank of South Sudan was established by an Act of Parliament (The Bank of South Sudan Act, 2011). By July 18 2011, the first major task the Central Bank of South Sudan undertook was to replace the Sudanese pound with the South Sudanese pound (SSP), which was by then being used as the domestic currency in the country (Samuel, 2011). The SSP was issued in six different denominations $(1,5,10,50,100$, and 200) in the form of banknotes. The currency was at first set at the same exchange rate as the Sudanese pound. understanding and awareness of the conditions under study and be able to communicate these to the public. One of those tools is a conceptual model, which helps illustrate the causal relationships between the independent and the dependent variables.

Accordingly, the conceptual model for this study is designed as shown in Figure 1.

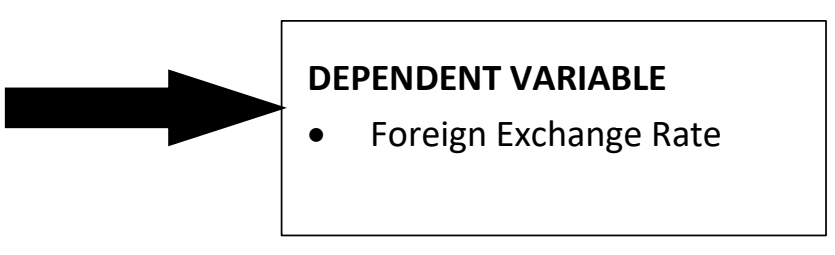

Now with full autonomy which was not the case under BOSS, the Central Bank of South Sudan was expected to commence deploying the right monetary policy instruments so as to maintain stability in the exchange rate, inflation rate and efficiency of the banking system in the country. In the early years of independence, that is from 2011 to 2015 , the value of the SSP was stable against the US dollar (USD) and the inflation rate was stable as well. The Treasury bill programme and a moderate rate of interest were effectively implemented. In addition, during this period (2011-2015), the amount of money (money supply) in circulation was manageable, and the country was able to maintain the required foreign exchange reserves. However, during the period 2016 to 2019, the worst economic crisis in the country's history set in. This could have been triggered by the implementation of the wrong monetary policy instruments through other factors such as 2013 civil and COVID-19, just to mention a few, which could also have played a contributory role. The SSP depreciated drastically against the USD, the annual inflation rate increased by more than $165 \%$ and revenues declined. They are now far below the budget requirements, resulting in the country running a large budget deficit (Jefferis, 2015).

125 This work is licensed under a Creative Commons Attribution 4.0 International License. 


\section{Exchange Rate Dynamics in South Sudan from} 2012 to 2019

An exchange rate is one of the monetary policy instruments the South Sudan Central Bank adopted since it gained its independence in July 2011. However, its fluctuations for the past eight years have been a major obstacle the country's economy faced in macroeconomic management. Two types of different exchange rate regimes were deployed in different phases. During the period 2011 to November 2016, the country implemented a fixed exchange rate, where the official exchange rate of SSP against USD was at SSP 3/USD1. During this period (2011 to November 2016), the South Sudan Central Bank was able to maintain a fixed exchange rate, the value of SSP was very strong against the USD and the inflation rate was manageable.

However, in December 2016 the South Sudan Central Bank adopted a floating exchange rate policy coupled with a devaluation of the SSP. Immediately after the implementation of the flexible exchange rate policy, the SSP began losing its value drastically against the USD. In December 2015 it depreciated from SSP 3.6 per USD to SSP 46.7 per USD in 2016 and the depreciation continued until it reached SSP 158 per USD in 2019 (World Bank, 2019). Although the Central Bank put the SSP at such values against the USD in those years, the actual values where ordinary citizens/traders could get USDs in the black market were by far higher than these values use in this study.

Although the implementation of the floating exchange rate policy could be seen to be the major cause of SSP depreciation against the USD, adjustments in other monetary policy instruments such as a reduction in foreign exchange reserves and an increase in the growth rate of money supply contributed significantly to these continual fundamental exchange rate fluctuations in the country. In this paper, the cause of these fluctuations is examined using foreign exchange reserves and money supply data which are transformed into natural log units because coefficients on the natural log scale are directly interpretable as approximate proportional differences.

\section{Effects of Foreign Exchange Reserves on Exchange Rate}

South Sudan's foreign exchange reserves have been decreasing drastically since 2012 . The decrease was caused by some factors such as the 2012 temporary shutdown of oil production in response to Sudan's unilateral decision to confiscate South Sudan's oil in exchange for the use of Sudan's pipeline, the December 2013 civil war and the implementation of wrong monetary policy instruments. Accordingly, the lack of maintaining the required foreign exchange reserves has now significantly contributed to the deterioration of the foreign exchange rate. In August 2020, Mr. Daniel Kech Pouch, second deputy governor of South Sudan Central Bank stated that "It is difficult for us at the moment to stop this rapidly increasing exchange rate, because we do not have resources, we do not have reserves" (Dumo, 2020).

Figure 2 presents the analysed results of foreign exchange reserves and exchange rate for the period 2012 to 2019. The results show that a decrease in foreign exchange reserves causes a depreciation of the exchange rate. This is in agreement with the findings of Kasman and Ayhan (2008), Yu and Lili (2011) and Hoshikawa (2012). 
East African Journal of Business and Economics, Volume 3, Issue 1, 2021

Article DOI: https://doi.org/10.37284/eajbe.3.1.353

Figure 2: Foreign Exchange Reserves and Exchange Rate in South Sudan

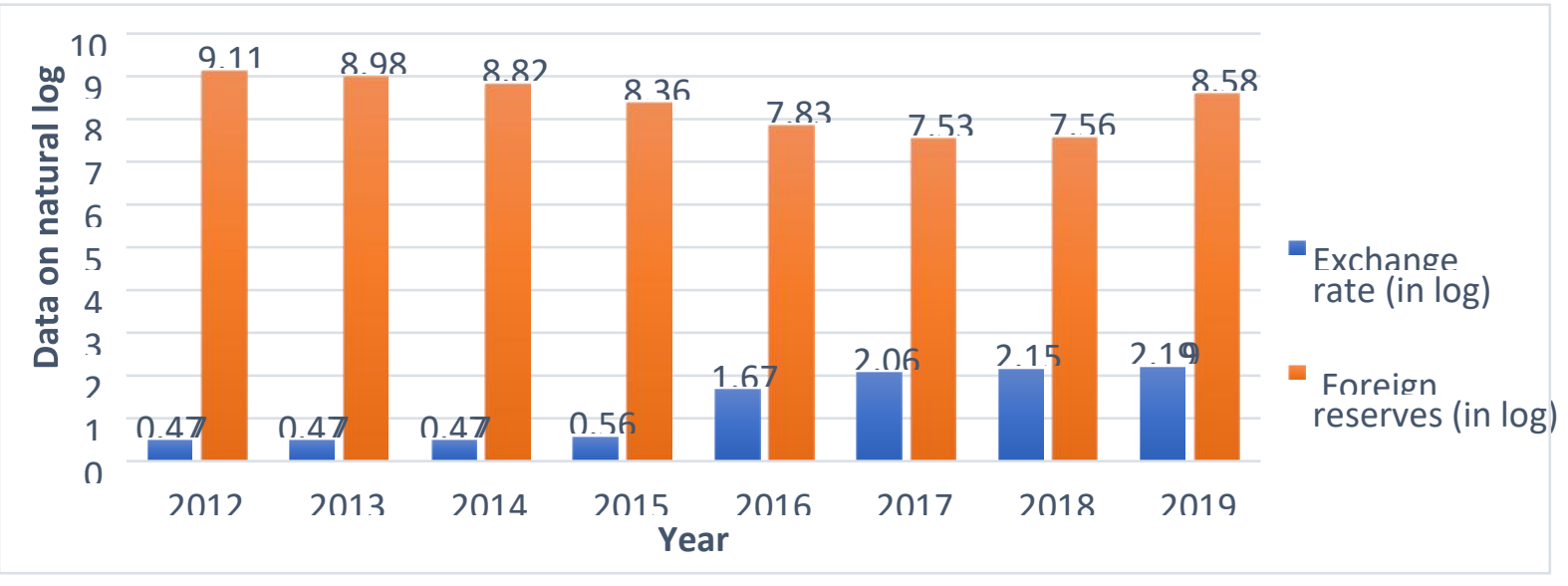

From 2012 to 2014, the exchange rate in South Sudan was stable because the foreign exchange reserves required for the country were sufficient to support its income or trade.

However, from 2015 to 2017 there was a drastic decrease in the country's foreign exchange reserves and as a result, the exchange rate depreciated. In 2018 and 2019, there was a small increase in the foreign exchange reserves; however, the amount did not meet the required threshold needed to correct the shock created in the market. Thus, the exchange rate continued deteriorating as shown in Figure 2.

controlling the money supply through the monetary policy. As of 2012, 2013 and 2014, the growth rate of the money supply was in alignment with the country's economic growth. However, from 2015 to 2019, South Sudan Central Bank decided to deploy an expansionary monetary policy whereby a large amount of SSPs was released into the economy in order to meet certain short-term needs. Unfortunately, this exacerbated the inflation rate and exchange rate depreciation. The extreme increase of SSP supplies led to the lowest value it is now experiencing against the USD in the market.

\section{Effects of Money Supply on Exchange Rate}

From the time of its establishment, the South Sudan Central Bank has been in charge of monitoring and

Figure 3: Money supply and exchange rate in South Sudan

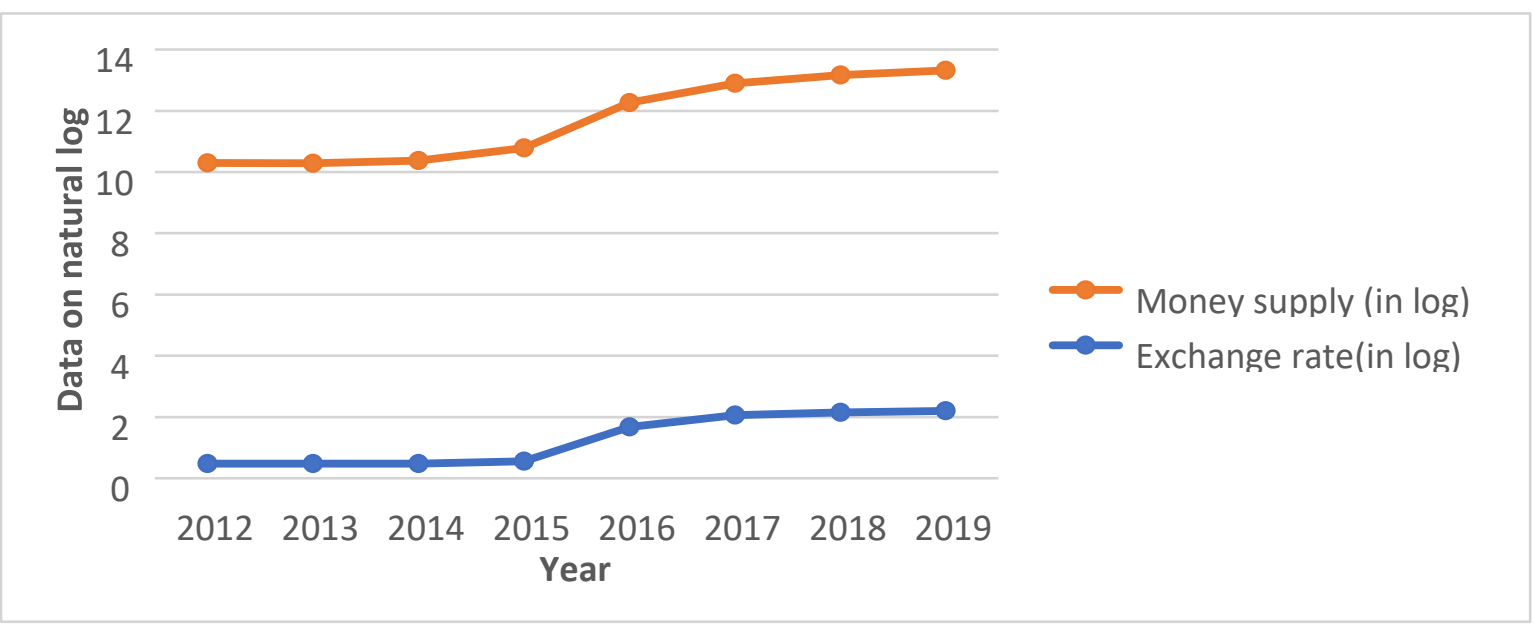

127| This work is licensed under a Creative Commons Attribution 4.0 International License. 
Figure 3 presents the analysed results of the money supply and exchange rate for the period of 2012 to 2019. The results show that an increase in money supply results in exchange rate depreciation. This is in agreement with the findings of studies such as those of Raza and Afshan (2017), Arikekpar (2020) and Vasani et al. (2019).

\section{CONCLUSION AND RECOMMENDATIONS}

The main object of this study was to examine the effect of foreign exchange reserves and money supply on the exchange rate in South Sudan for the period 2012 to 2019 through the lens of a review of theoretical literature and a graphical analysis of a few available data. The graphical analysis results of this study reveal that a decrease in foreign exchange reserves causes depreciation in the exchange rate. The results also indicate that an increase in money supply causes depreciation in the exchange rate. The findings are in line with the findings of all the empirical studies that are reviewed in this paper.

In line with these results and other studies related to this topic, the policy recommendations for this study would be the following: Firstly, since it is confirmed by the findings that a decrease in foreign exchange reserves causes an increase in exchange rate depreciation, this study would suggest that the best approach the South Sudan Central Bank and monetary policymakers could adopt to stabilise the exchange rate in the country would be to increase foreign exchange reserves to a level which is able to correct the current or any financial market turbulence in the future. Secondly, as the finding indicates that an increase in the money supply causes depreciation in the exchange rate, this study would recommend that the best approach that the South Sudan Central Bank and monetary policymakers could adopt is to deploy a contractionary monetary policy because this will cause a decline in the level of money supply and eventually a lower exchange rate depreciation in the country.

\section{REFERENCES}

Ajakaiye, O. (1995). Short run macroeconomic effects of bank lending rates In Nigeria, 198791: A computable general equilibrium analysis.
Nairobi, KE: African Economic Research Consortium.

Aleksandra, E. Z. (2019). The importance of exchange rate stability for export growth. Proceedings of International Academic Conferences. International Institute of Social and Economic Sciences.

Anyanwu, J. C. (1993). Monetary Economics: Theory, policy, and Institutions. Hybrid Publishers.

Arikekpar, A. O., 2020. The relationship between exchange rate volatility and monetary policy shocks in Nigeria. IIARD International Journal of Banking and Finance Research, 6(3), 41-53.

Dumo. D. (2020, August 19). South Sudan central bank says foreign exchange reserves have run out. The Thomson Reuters Trust Principles. Retrieved on March 20, 2021 from https://www.reuters.com/article/us-southsudancenbank-idUSKCN25F2DS.

Frieden, J. A. (2016). Currency Politics: The political economy of exchange rate policy. Princeton University Press

Glavan, B. (2006). The role of foreign exchange reserves: another viewpoint. Romanian Economic and Business Review, 1(4), 61.

Hoshikawa, T. (2012). Regime shift of Japanese foreign exchange policy: some findings. Applied Economics Letters, 19(1), 25-28.

Jefferis. K. (2015, October 14). Exchange rate reform in South Sudan. Retrieved on February 28, 2021 from IGC, https://www.theigc.org/session/exchange-ratereform-in-south-sudan-keith.

Kashif, M., \& Sridharan, P. (2015). International reserves accumulation and economic growth: Evidence from India. International Journal of Engineering and Management Research, 5(2).

Kasman, A., \& Ayhan, D. (2008). Foreign exchange reserves and exchange rates in Turkey: Structural breaks, unit roots and cointegration. Economic Modelling, 25(1), 8392. 
Obura, J. M., \& Anyango, C. (2016). Moderating effect of interest rates on relationship between foreign exchange rate fluctuation and performance of Nairobi securities exchange market. Universal Journal of Accounting and Finance, 4(2), 27-34.

Raza, S. A., \& Afshan, S. (2017). Determinants of exchange rate in Pakistan: Revisited with structural break testing. Global Business Review, 18(4), 825-848.

Samuel. A. (2011, July 8). South Sudan to issue new currency on July 9. Available online at http://jubapost.org/article-50.html.

Semuel, H., \& Nurina, S. (2014). Analysis of the effect of inflation, interest rates, and exchange rates on Gross Domestic Product (GDP) in Indonesia. Doctoral dissertation. Petra Christian University.

Sercu, P. (2009). International Finance: Theory into Practice. London: Princeton University Press.

Vasani, S. A., Selvam, M., \& KATHIRAVAN, C. (2019). Relationship between Real Exchange Rate and Economic Growth in India. ZENITH International Journal of Business Economics \& Management Research, 9(3), 19-35.

World Bank. (2019). Africa development indicators 2019: From the World Bank Africa Database. The World Bank.

Wyplosz, C. (2007). Debt sustainability assessment: The IMF approach and alternatives. Geneva: Graduate Institute of International Studies.

Yongo-Bure, B. (2015). Chapter 9: Southern Sudan: Monetary and Financial Policies and the Case for a Separate Currency. In Wassara, W. S. \& alAbdin, A. Z. (eds), Post-Referendum Sudan National and Regional Questions, (pp. 159-190). Dakar, Sudan: CODESRIA

Yu, F. \& Lili, L. (2011). Does a correlation exist between the foreign exchange reserves and the exchange rate?: An empirical study of China. Umeå School of Business, Economics and Statistics, Umeå University.

129| This work is licensed under a Creative Commons Attribution 4.0 International License. 